\title{
Investment Scenarios in the Clonal Conilon Coffee Planting with an Irrigated System: A Study in a City from Rondônia, Brazil
}

\author{
Camila Dutra Santos de Morais ${ }^{1}$, Sandra da Cruz Garcia ${ }^{1}$, Júlio Sancho Militão ${ }^{1}$, Davy Ítalo Ribeiro da Silva ${ }^{1}$, Francisco \\ Cordeiro Júnior ${ }^{1}$, Viviane Barrozo da Silva ${ }^{1}$, Sueli da Cruz Garcia ${ }^{1}$, Haroldo de Sa Medeiros ${ }^{1}$ \\ ${ }^{1}$ Universidade Federal de Rondônia, Brazil \\ Correspondence: Sandra da Cruz Garcia, Universidade Federal de Rondônia, Brazil.
}

Received: October 16, 2020

doi:10.11114/ijsss.v9i1.5056

\author{
Accepted: December 3, $2020 \quad$ Available online: December 28, 2020
}

URL: https://doi.org/10.11114/ijsss.v9i1.5056

\begin{abstract}
This article aims to analyze the financial feasibility of implementing a clonal conilon coffee crop in the State of Rondônia. For this, a research with quantitative procedures was carried out, having as a locus of research a property in the municipality of Nova Brasilândia D'Oeste, interior of the state of Rondônia (Brazil). Based on the assumption that investments are made to generate value for the investor, the expenses incurred and estimates of future expenses were measured, with two scenarios, the first with the presence of the plague (scale) and the second without the presence of the same. Therefore, it became possible to analyze the valuation methods through the projections of Net Present Value, Internal Rate of Return and Payback. With these results, an analysis of the financial viability of the crop in question was carried out, which demonstrated a significant expense in the first years for the small producer, having a return from the fifth year on, proving to be financially viable and advantageous.
\end{abstract}

Keywords: clonal conilon coffee, irrigated system, financial viability, investment, scenarios

\section{Introduction}

Brazil's agro-industrial coffee system in recent years has been the subject of several studies and research, leading to the expansion of the development of better coffee seedlings, contributing to the increase in production and maintaining the country in its current position as the world's largest coffee exporter. The state of Rondônia has been cooperating with this indicator, representing the fifth largest coffee producer in Brazil, and the second largest producer of conilon coffee (Embrapa, 2018a).

The production of RO, with the adoption of techniques of better cultivation with the use of clones of conilon coffee in substitution to common conilon coffee, has been collaborating with the increase of coffee production. The method of genetic improvement of the plant of the robusta group (conilon), or by selection of the best plants of the crop to carry out the clone by means of sprouts is the most used by producers of coffee seedlings in nurseries in the state (Emater-RO, 2019).

In Rondônia state, 35 counties in the state benefited from the program to revitalize coffee crops, including Rolim de Moura, Ji-Paraná, Urupá and Cacoal (Governo de Rondônia, 2017). Given this context, in order to investigate the feasibility of the enterprise for the transition of clonal coffee crops, the following question is necessary: What is the financial feasibility in the transition from a common coffee culture to that of clonal coffee?

Based on this question, the general objective of this research was to analyze the financial feasibility of the transition of clonal coffee in a rural property inserted in the context of coffee production in Rondônia.

This study is justified in view of the need to analyze what is the financial feasibility in the cultivation of new genetically modified plants for better production. It seeks to contribute to a greater understanding of the feasibility of an enterprise for the transition from common coffee to clonal coffee and can provide more information on investment for rural producers who are aiming to start the development of clonal coffee production.

\section{Theoretical Reference}

\subsection{Coffee in Rondônia}

Coffee emerged in the Amazon in the 18th century. More specifically, in the state of Rondônia, it turned up around the 
second half of the 20th century, where significant areas of coffee began to be implemented. Thus, in the mid-1970s, the new Amazonian experience of "black gold" was the result of pioneers, mainly from Paraná, Minas Gerais and Espírito Santo. Those responsible for the colonization of Rondônia brought with them the culture cultivated in their states of origin: the people from Paraná and Minas Gerais brought arabica coffee and capixabas, canephora coffee, especially those from the Conilon group (Marcolan et al. 2015).

Still according to the author, the coffee culture was quickly established in the State, due to some factors such as:

- Immigrants seeking better living conditions by occupying land along Highway BR 364, which cuts through the state in a southeast-northwest direction;

- State and federal actions, which aimed to improve production conditions;

- Climatic and soil conditions that allowed an advantageous condition for production.

In addition, another important factor for coffee development in Rondônia was the better adaptation of Conilon coffee. This type of coffee has become more advantageous due to the "average maturation cycle that is longer than arabica coffee, allowing the harvest not to occur in the rainy season. As well as, it has more resistance to the hybrid period in the Amazon, which occurs between the months of May to September (Marcolan et. al., 2015).

Currently, the state of Rondônia in the national ranking of 2018, in coffee production is classified in fifth place, with a production of 2.19 million sacs. Given the national classification, the State is the second largest producer of robusta coffee in the country, with 71,605 thousand hectares (19.1\%) behind the state of Espírito Santo, which has 231,323 thousand hectares and is equivalent to $61.6 \%$ of the cultivation with this species (Embrapa, $2018 \mathrm{a}, \mathrm{b}$ ).

Rondônia has six poles of coffee regions that were defined based on geographic positioning, period of official colonization of the region, and the importance of the activity in the local and state context, they are: Vale do Jamari, Ji-Paraná, Cacoal, Rolim de Moura, Machadinho d'Oeste and Vale do Guaporé (Marcolan et al, 2009). The largest production of coffee in the state is concentrated in the counties of Alto Alegre do Parecis, Alta Floresta do Oeste, Cacoal, Ministro Andreazza, Nova Brasilândia do Oeste and São Miguel do Guaporé. (Diary of the Amazon, 2018).

It is defined by the Federal Institute of Rondônia (Ifro, 2019), that coffee production in the state provides income to more than 22 thousand families, and point that it is of great socioeconomic importance. Thus, coffee, in addition to generating income, guarantees the permanence of men in the field.

Another important factor for guaranteeing the income of rural people in Rondônia is that, in recent years, coffee growing in Rondônia is undergoing transformations in terms of coffee productivity and quality. This factor has been occurring due to the implementation of new technologies. With these technologies in place, there was a $42.9 \%$ decrease in planted area, while productivity increased by $99.8 \%$ (Embrapa, 2016).

Following are Table 01, which presents coffee production in the State of Rondônia, shows the reduction of the cultivated area in the State of Rondônia, the increase in productivity in processed bags and coffee productivity.

Table 1. Coffee production in the State of Rondônia

\begin{tabular}{|l|c|c|c|}
\hline Year & $\begin{array}{l}\text { Area in Coffee Production (in } \\
\text { hectares) }\end{array}$ & $\begin{array}{l}\text { Coffee production } \\
\text { (in thousand sacs benefited) }\end{array}$ & $\begin{array}{l}\text { Coffee Productivity } \\
\text { (in sacs / hectare) }\end{array}$ \\
\hline $\mathbf{2 0 1 3}$ & 102.840 & 1.357 & 13,2 \\
\hline $\mathbf{2 0 1 4}$ & 86.004 & 1.477 & 17,2 \\
\hline $\mathbf{2 0 1 5}$ & 87.657 & 1.724 & 19,7 \\
\hline $\mathbf{2 0 1 6}$ & 87.657 & 1.627 & 18,6 \\
\hline $\mathbf{2 0 1 7}$ & 74.255 & 1.938 & 26,1 \\
\hline $\mathbf{2 0 1 8}$ & 63.879 & 1.978 & 30,97 \\
\hline
\end{tabular}

Source: Prepared by the authors, adapted from the National Supply Company (CONAB) - Agricultural Indicators (2017; 2019).

One of the technologies adopted for better coffee productivity is the management of clonal coffee, which are seedlings that have a better quality genetic material, together with other associated practices, we have "proper crop management, good agricultural practices and management of coffee activity, irrigation, pruning performed in conjunction with fertilizing or/and plant nutrition [...]" (Embrapa, 2016).

Therefore, the Government of Rondônia, with the objective of strengthening and increasing agriculture in relation to coffee produced in the state, initiated, through the Secretariat of Agriculture (SEAGRI) and the Municipality of Technical Assistance and Rural Extension of the State of Rondônia (EMATER -RO), a clonal coffee seedling distribution program in 2016 to boost the transition from common coffee to clonal coffee crops. This distribution took place through partnerships with other departments based on the local demands of each region of the state, together with the monitoring of EMATER-RO. In total, in the last three years, more than three million seedlings of clonal coffee have 
been distributed, benefiting several coffee growers in the State (Emater-RO, 2017, 2019).

Ramalho (2016) argues that genetic improvement in Rondônia started from the 1990s by EMBRAPA, using tests of clonal plants of the Conilon coffee tree. With it first field experiments in 1998.

Next, it will be discussed, which subdivisions presents the coffee, the most cultivated and its main characteristics.

\subsection{Coffee cultivars}

The genus Coffea is subdivided into several species, but the cultivation of Coffea arabica predominates with a total of 104 species, including Catuaí, Mundo Novo, Acauã, Catucaí. Coffea canephora in turn has 10 species of cultivation including Robusta, Kouilou, Apoatã and Guarini (Carvalho, 2008).

Arabica is characterized by being milder, with a more pronounced aroma and flavor. Canephora, on the other hand, known as conilon and robusta coffee, is characterized by being more neutral and containing a bitterness, but with a higher content of caffeine and soluble solids, also presenting a higher production index (Ferrão, 2017).

Robusta coffee, known in Brazil as conilon, was introduced in the country by the State of Espírito Santo in 1912, brought by Jerônimo Monteiro, former governor of the State (Bandes, 1987; M. Ferrão et. al., 2007; R. Ferrão et. al., 2007; Merlo, 2012; Vargas, 2012 apud Ferrão, 2017).

According to Ferrão et al (2017), for the realization of the coffee clone, the main means is the vegetative selection, where plants with the best performance and the fastest way to capitalize gains are selected to carry out the experiment. Furthermore, "a clone can be defined as a set of individuals genetically derived from a single plant and propagating through vegetative means, such as cuttings, branches and buds, among others".

A major driver of clonal cultivation is high production compared to the productivity of seminal coffee (Souza, 2018). According to EMATER-RO (2016), clonal coffee reaches a production of more than 100 sacs/hectare, whereas ordinary/seminal coffee produces an average of 10 sacs/hectare.

Moreover, seminal coffee has a major disadvantage of lack of uniformity of production in relation to clonal coffee, because in this cultivation the plants are derived from seed germination. Due to this production disadvantage, farmers started to invest in seedlings from cloning (Partelli, 2011). Seminal coffee has genetic characteristics similar to that of the mother plant, such as resistance, tolerance, and productivity (Souza, 2018). On the other hand, cloned seedlings are more sensitive and need more care regarding survival in the field, requiring mainly irrigation in the hybrid period (Espindula \& Partelli, 2011).

In addition, clonal coffee provides farmers with production planning based on the maturity cycle of the cultivated variety. This cultivation provides a homogeneous and quality harvest. In this type of production, the major disadvantage is also maturation, due to which it may occur that at the end of the harvest the fruits are already past the maturation process (Souza, 2018). Table 02 presents a comparison of the advantages and disadvantages between coffee seminal and clonal coffee.

Table 2. Advantages and disadvantages between seminal and clonal coffee

\begin{tabular}{|l|r|r|}
\hline \multirow{2}{*}{ Analyzed variable } & Seedlings & \multicolumn{2}{|c|}{ Clonal } \\
\cline { 2 - 3 } & Seminal & \multicolumn{2}{|c|}{ Inconsistent information } \\
\hline Growth of the root system & \multicolumn{2}{|c|}{ Inconsistent information } \\
\hline Plant Survival in the Field & - & - \\
\hline Seedling production facility & + & + \\
\hline Crop implantation cost & - & - \\
\hline Grain production stability & - & + \\
\hline Field plant management & - & + \\
\hline Production precocity & - & + \\
\hline Grain productivity & - & + \\
\hline Drink quality & - & + \\
\hline Economic return & - & + \\
\hline
\end{tabular}

Source: Adapted from Espindula and Partelli (2011). (+) Superior and (-) inferior in relation to the other propagation method.

Espindula and Partelli (2011) argue that clonal coffee, despite having a higher cost for implantation, the advantages related to this cultivation surpass the disadvantages. Therefore, "clonal coffee has attracted the attention of farmers due to its productivity potential, smaller planting area and higher income generated" (Centro De Estudos Rio Terra, 2016).

Although clonal coffee is more advantageous, another factor to be analyzed is the coffee tree arthropods, which can directly affect the plant's development. The main pests present in the coffee culture in the Amazon are: the coffee borer, the red mite, the miner bug, the coffee caterpillar, mealybugs, rosette caterpillar. They are responsible for generating 
large coffee losses in the region and have been causing concern and losses to the producer, but which can be controlled by biological or chemical means (Marcolan et al., 2015).

Asserts Marcolan et al. (2015), that to obtain a good development of a coffee area, it is essential to follow some procedures to obtain a better performance, as well as, it is necessary to make the crop maintain a good condition to reach the maximum or expected production.

According to the author, the following procedures are necessary for the implantation of a crop:

a. Definition of the location and preparation of the ground: the implantation and the initial management of the crop are essential for the success of the coffee cultivation, on the other hand, the planting in inadequate places, besides hindering the formation and conduction of the coffee plantation, decreases the profitability of the producer;

b. Choice of area: the area must have a slope of less than 12\%; ground with good drainage; absence of dense layers; mechanizable (without rock outcrop and presence of stones and / or cuttings); effective soil depth above $1.0 \mathrm{~m}$; medium to clayey solo (15 to 60\% clay); and fertile and chemically balanced solo. When natural fertile areas are not available, soil acidity correction and fertilization should be carried out, according to technical guidance;

c. Preparation of the area: the use and management of the land imply different types of preparation of the area, which can be composed of capoeira area (recovery of the area), pasture area and opening area that is composed of newly deforested areas;

d. Demarcation of corridors and alignment: as a general rule, the demarcation of carriers or corridors at the coffee plantation level must be dependent on the topography of the terrain, moto-mechanization and the spacing to be used. The average width of the level carriers varies from $6 \mathrm{~m}$ to $7 \mathrm{~m}$ and that of the pending carriers from $4 \mathrm{~m}$ to $6 \mathrm{~m}$;

e. Seedlings: the producer can opt for the formation of seedlings by seed or nursery seedlings (seminal or clonal), for the formation of new coffee plantations;

f. Digging: the opening of holes can be mechanized or manual. In the mechanized opening, the hole can be made through the use of the drill, adopting the dimensions of $40 \mathrm{~cm} \times 40 \mathrm{~cm} \times 40 \mathrm{~cm}$ (length, width and depth), or mechanized grooving, using the furrower and with opening and depth of $50 \mathrm{~cm}$;

g. Planting: the months of December and January are recommended, which are the most suitable for planting coffee seedlings, on rainy or cloudy days and

h. Soil sampling: for the liming and fertilization recommendation, soil sampling is necessary, considering two situations: the formation of the coffee plantation (implantation in a new area) and the maintenance of the existing coffee plantation.

After carrying out the above procedures, planting clonal coffee is a perennial crop, that is, it produces once a year, and in order to have better results in coffee production, it is necessary, some procedures which the producer annually farm performs on your plantation. Thus, care ranges from the soil with the application of lime, fertilizer and urea (solid nitrogen fertilizer) to correct and strengthen the crop to care for the plant itself as it sprouts, which consists of removing excess bud and pruning the plant that is the removal of productive stems (Marcolan et al., 2015).

To understand the productivity of clonal coffee, the following are the feasibility indicators necessary to understand whether the project is financially acceptable.

\section{Methodology}

The methodological procedures of this article are characterized by being quantitative and descriptive. To meet the objective, two investment scenarios were developed, the first with the presence of the pest (scale) and the second without the scale.

For scenarios with the presence of scale and without the presence of scale, data collection took place in a farm located in the municipality of Nova Brasilândia D'Oeste, in the interior of the State of Rondônia, which, according to the Brazilian Institute of Geography and Statistics (IBGE) (2019), has an estimated 20,474 inhabitants.

The financial information was collected through a structured interview and was provided by the owner in relation to the period from December 2016 to November 2019, a period in which the transition occurred between the seminal conilon coffee crop and the conilon clonal coffee crop, considering the existence of irrigation in the field.

Data analysis was performed using the formulas of analysis and financial feasibility, which were described in item 2.3 above. Excel software was used as a tool to obtain the results.

\section{Results and Discussions}

The counties of Nova Brasilândia d'Oeste has a clonal coffee cultivation system with a productivity of 70 sacs per 
hectare, characterized mainly by high pressure cannon irrigation and soil fertility due to the use of fertilizer by technical recommendation, resulting in an expressive harvest in the second year (Marcolan et al., 2015)

The location is at line 14, and corresponds to a total of 9 bushels of unit of measurement of the agrarian area. But, the analyzed area is equivalent to 1 (one) bushel which is equivalent to 2.72 hectares of clonal conilon coffee plantation.

For the purposes of analyzing the result on that property, 6,000 (six thousand) seedlings of clonal conilon coffee were used. And the prices obtained in the analysis of the transition cost were raised in the referred city, considering, with this, the fair value price. According to the Accounting Pronouncements Committee (2012), fair value is "the price that would be received for the sale of an asset or that would be paid for the transfer of a liability in an unforced transaction between market participants on the measurement date".

During the research period on the property, the analysis between December 2016 and November 2019, the existence of expenses obtained until November/2019 and the estimates of profits and expenses for the period of the year 2020 were observed. Also the presence of invasive diseases (pests), such as scale insects and red mites, making it necessary to use pesticides for combat.

The table below shows the transition costs from an old crop to a new crop, which used new forms of cultivation.

Table 3. Transition from the old crop to the new crop

\begin{tabular}{|l|c|c|c|}
\hline \multicolumn{1}{|c|}{ Costs } & Amount & Unit value (R\$) & Values (R\$) \\
\hline Remove irrigation & 1 & & 500,00 \\
\hline Removing the old coffee & & & 2500,00 \\
\hline Area preparation/street demarcation & & & 500,00 \\
\hline
\end{tabular}

Source: Research data

Table 4. Transition from the old crop to the new crop

\begin{tabular}{|l|c|c|c|}
\hline Costs & \multicolumn{1}{|l|}{ Amount } & Unit value (R\$) & \multicolumn{1}{l|}{ Values (R\$) } \\
\hline Install irrigation & & & 500,00 \\
\hline Soil sampling & 2 & 90,00 & 180,00 \\
\hline Fertilizer coffee straw & 10 & 100,00 & 1000,00 \\
\hline Calcareous & $4.000 \mathrm{~kg}$ & & 280,00 \\
\hline Fertilizer & $20 \mathrm{sacos}$ & 100,00 & 2000,00 \\
\hline Seedlings & 6.000 & 0,70 & 4200,00 \\
\hline Seedling freight & 1 & & 300,00 \\
\hline Digging and planting & & & 2960,00 \\
\hline Daily & 10 & 80,00 & 800,00 \\
\hline Total & & & $15.720,00$ \\
\hline
\end{tabular}

Source: Prepared by the authors based on the research data.

It is observed in Table 03, that the cost for transition, that is, the removal of the old coffee until the planting phase of the new crop, following the technique recommended for cultivation according to EMBRAPA, from the definition of the place, until cultivation preparation, obtained an investment in this initial phase of $R \$ 15,720.00$ (fifteen thousand seven hundred and twenty reais). This value is significant for the small rural producer, who in some cases uses financing from financial institutions to carry out the entire project, but this did not happen to the owner under study, the investment was with equity.

The table below shows the annual expenses for the first harvest, which is different from the others due to the size of the coffee trees. 
Table 5. Annual expenditure on the first harvest

\begin{tabular}{|l|c|c|c|}
\hline \multicolumn{1}{|c|}{ Expenses } & Quantity/Time & Unit value (R\$) & Values (R\$) \\
\hline Electricity & 1 trimester & & 840,12 \\
\hline Soil sampling & 1 & 90,00 & 90,00 \\
\hline Fertilizer & 12 bags & 85,00 & $1.020,00$ \\
\hline Urea & $9 \mathrm{bags}$ & 60,00 & 540,00 \\
\hline Pesticides & - & - & $1.165,00$ \\
\hline Blooms & 1 & 100,00 & 100,00 \\
\hline Daily & 44 & 50,00 & $2.200,00$ \\
\hline Contract & 6 & 200,00 & $1.200,00$ \\
\hline HARVEST & & & \\
\hline Sacs & 45 & 280,00 & $3.240,00$ \\
\hline Can brass* & 810 & 4,00 & $1.575,00$ \\
\hline Drying & 45 & 35,00 & 165,37 \\
\hline FUNRURAL & 45 & $1,5 \%$ & $12.135,49$ \\
\hline Total & & & \\
\hline
\end{tabular}

Source: Prepared by the authors based on the research data

* Can brass: Crop measurement unit: contains 20 liters.

Table 04 shows the costs of farming after planting the coffee seedlings until the time of the first harvest. According to the owner, the period for the first collection is one year and four months, which usually takes place in March or April. Thus, planting took place in December 2016 and the first harvest took place in April 2018.

It was also observed that the time spent on energy for irrigation of crops was one quarter, these being the months of July, August and September, which represent the period of drought in the State. Thus, as clonal coffee is more sensitive to solar radiation, irrigation is needed during this period so as not to damage it with the region's hot climate.

Regarding pesticides, it has been used since sprayed on trees and on the farm floor, being purchased in kilos, liters or gallons. The daily rates include cleaning the crop, spraying pesticides, spreading fertilizer and urea.

Another important factor was the amount spent on the first harvest, a price of $\mathrm{R} \$ 4,00$ per can brass, a high value, since the value is usually $R \$ 2,00$. According to the farmer, the increase in value occurred as a result of the lack of labor caused by the high difficulty with the first harvest, as the coffee trees are still very small and take longer during the procedure.

On average, 18 cans are needed to compose a $60 \mathrm{~kg}$ sac. In addition to the value of the harvest, an additional $\mathrm{R} \$ 35,00$ per sac is spent to carry out drying and cleaning to compose the sac. At the same time, $1.5 \%$ is also spent on the Rural Worker Assistance Fund (FUNRURAL) discounted after the amount spent per bag. In other words, the farmer, when selling his production, received $\mathrm{R} \$ 280,00$ per sac, but drying and FUNRURAL are deducted from that amount.

FUNRURAL, "is a social security contribution tax, levied on gross revenue from the sale of rural production". Intended for the National Institute of Social Security (INSS), Environmental Risks of Work (RAT) and the National Service for Rural Learning (SENAR) (FANTINI, 2019).

Then, in Table 06, the annual expense for the second harvest is shown.

Table 6. Annual expenditure on the second harvest:

\begin{tabular}{|l|c|c|c|}
\hline \multicolumn{1}{|c|}{ Expenses } & Quantity/Time & Unit value (R\$) & \multicolumn{1}{l|}{ Values (R\$) } \\
\hline Electricity & 1 trimester & 912,34 \\
\hline Soil sampling & 1 & 90,00 & 90,00 \\
\hline Fertilizer & 9 sacs & 105,00 & 945,00 \\
\hline Ureia & 12 sacs & 85,00 & $1.020,00$ \\
\hline Pesticides & & & $1.805,00$ \\
\hline Blooms & 2 & 400,00 & 800,00 \\
\hline Pruning & 1 & 810,00 & 810,00 \\
\hline Daily & 60 & 60,00 & $3.600,00$ \\
\hline HARVEST & 136 & & \\
\hline Sacs & 2.448 & 300,00 & - \\
\hline Can brass & 136 & 2,00 & $4.896,00$ \\
\hline Drying & 136 & 35,00 & $4.760,00$ \\
\hline FUNRURAL & & $1,5 \%$ & 540,60 \\
\hline Total & & & $20.178,94$ \\
\hline Source: Prepred
\end{tabular}

Source: Prepared by the authors based on research 
Table 05 shows the expenses with the second harvest, with emphasis on the increase in the use of pesticides, which was the result of the increase in scale in the crop. Consequently, the number of daily allowances to spray it was also increased.

There is also an increase in coffee production in the second year of harvest, which increased from 45 to 136 sacs of 60 $\mathrm{kg}$. According to the farmer, the harvest was no longer significant due to the presence of scale insects, which affected production. But still, it was observed that the values of the expenses with the harvest are variable, as the production increases or decreases the costs, that is, the higher the production, the higher the costs.

Tables 07 and 08 presented two different scenarios of estimates: scenario 01 does not occur the scale insects in the following years; scenario 02 is the presence of the mealybug, and how it can affect the viability indicators.

Table 7. Scenario 01: Estimated crop expenses in the third harvest without the presence of invasive pests

\begin{tabular}{|l|c|l|l|}
\hline Expenses & Quantity/Time & Unit value (R\$) & Values (R\$) \\
\hline Electricity & 1 trimester & & 912,34 \\
\hline Soil sampling & 1 & 90,00 & 90,00 \\
\hline Fertilizer & 9 sacs & 105,00 & 945,00 \\
\hline Ureia & 12 sacs & 85,00 & $1.020,00$ \\
\hline Pesticides & & & $1.165,00$ \\
\hline Blooms & 2 & 400,00 & 800,00 \\
\hline Pruning & 1 & 810,00 & 810,00 \\
\hline Daily & 65 & 60,00 & $3.000,00$ \\
\hline HARVEST & & & \\
\hline Sacs & 150 & 291,58 & - \\
\hline Can brass & 2.700 & 2,00 & 5400,00 \\
\hline Drying & 150 & 35,00 & $5.250,00$ \\
\hline FUNRURAL & 150 & $1,5 \%$ & 577,75 \\
\hline Total & & & $19.970,09$ \\
\hline
\end{tabular}

Source: Prepared by the authors based on research

Table 07 shows the estimates of crop expenses in the third harvest. It was developed with data collected from the farmer, using Table 05 as a reference, which provides for expenses with the second harvest.

According to the producer, the estimate will depend on the crop, its leafing, the branches, the presence of pests in the coffee plantation, considering the productive capacity. Thus, it can be estimated that the 2020 harvest will be 150 sacs, based on the fact that scale insects do not occur in the crop in the year under study.

The other values according to him will continue, because, in fact, the amount spent on energy occurs every year in 3 months, the fertilizer and urea are spent according to the indication of the soil sampling. The amount spent on pesticides decreased due to the absence of scale, being considered the amount based on the first year spent where it did not occur.

The value of the sac that was calculated based on the average obtained through the information from CEPEA / ESALQ (2019), between the months of January to November 2019, totaling an average value of 291.58 to sac of the $60 \mathrm{~kg}$.

Table 08 will show estimates of crop expenses for the third harvest. It was developed with data collected from the farmer, using Table 05 as a reference, which provides for expenses with the second harvest, but with changes in the presence of scale insects in the next productive years.

Table 8. Scenario 02: Estimated crop expenses in the third harvest with the presence of invasive pests

\begin{tabular}{|l|l|l|l|}
\hline Expenses & Quantity/Time & Unit value (R\$) & Values (R\$) \\
\hline Electricity & 1 trimester & & 912,34 \\
\hline Soil sampling & 1 & 90,00 & 90,00 \\
\hline Fertilizer & 9 sacs & 105,00 & 945,00 \\
\hline Ureia & 12 sacs & 85,00 & $1.020,00$ \\
\hline Pesticides & & & $1.805,00$ \\
\hline Blooms & 2 & 400,00 & 800,00 \\
\hline Pruning & 1 & 810 & 810,00 \\
\hline Daily & 60 & 60,00 & $3.600,00$ \\
\hline HARVEST & & & \\
\hline Sacs & 136 & 291,58 & - \\
\hline Can brass & 2.448 & 2,00 & $4.896,00$ \\
\hline Drying & 136 & 35,00 & $4.760,00$ \\
\hline FUNRURAL & 136 & $1,5 \%$ & 540,60 \\
\hline Total & & & $20.161,76$ \\
\hline
\end{tabular}

Source: Prepared by the authors based on research 
The estimate calculated in Table 07 was developed with the number of bags harvested in the second harvest, which showed a total of 136 sacs due to the presence of scale insects, representing a reduction of just under $10 \%$ (14 sacs) in relation to a good productive year according to the farmer.

According to the producer, the factors that increase with the presence of the scale insects are the amount of pesticides to combat and the amount of daily allowances that will be paid, because with the pest on the farm it demands a greater amount of pesticide use, therefore more days worked .

Based on Scenario 01, without the presence of the invasive pest and Scenario 02, admitting the presence of scale insects, it is noted that the amount in expenses was a difference of $\mathrm{R} \$ 191,67$, a total of $0.95 \%$. to the fact that the values with the harvest are variable.

Thus, it is noticed that the crop without the presence of scale insects presents lower expenses with pesticides and higher costs with the harvest, due to the fact of obtaining greater production. Scenario 02 shows that with the presence of the invasive pest, the amounts spent on pesticides are higher, but the costs with the harvest are lower, because less has been produced.

Table 09 presents the project's result, based on the data collected from the expenditure estimate for the next harvest.

Table 9. Project Outcome

\begin{tabular}{|l|l|l|l|l|l|}
\hline \multicolumn{1}{|c|}{ Year 0 } & \multicolumn{1}{c|}{$\mathbf{1}^{\circ}$ year } & \multicolumn{1}{c|}{$\mathbf{2}^{\circ}$ year } & $\mathbf{3}^{\circ}$ year & $3^{\circ}$ year \\
\hline $\begin{array}{l}\text { Pnitial } \\
\text { investment }\end{array}$ & $\mathrm{R} \$ 15.720,00$ & - & - & - & - \\
\hline Expenses & 0 & $\mathrm{R} \$ 12.135,49$ & $\mathrm{R} \$ 20.178,94$ & $\mathrm{R} \$ 19.970,09$ & $\mathrm{R} \$ 20.161,76$ \\
\hline Quantity of sacs & 0 & 45 & 136 & 150 & 136 \\
\hline Sac Value & 0 & $\mathrm{R} \$ 241,32$ & $\mathrm{R} \$ 261,02$ & $\mathrm{R} \$ 252,73$ & $\mathrm{R} \$ 252,73$ \\
\hline Gross profit & 0 & $\mathrm{R} \$ 10.859,40$ & $\mathrm{R} \$ 35.498,72$ & $\mathrm{R} \$ 37.909,50$ & $\mathrm{R} \$ 34.371,28$ \\
\hline Net profit & 0 & $-\mathrm{R} \$ 16.996,09$ & $-\mathrm{R} \$ 1.676,31$ & $\mathrm{R} \$ 16.263,10$ & $\mathrm{R} \$ 12.533 .21$ \\
\hline Revenues & 0 & 0 & 0 & $\mathrm{R} \$ 16.263,10$ & $\mathrm{R} \$ 12.533 .21$ \\
\hline
\end{tabular}

Source: Prepared by the authors

The result was obtained initially through the initial investment, followed by the expense of the first year which resulted in a negative balance of $-\mathrm{R} \$ 16.996,09$ after adding the expenses of the first year with the initial investment. Subsequently, the second year resulted in a harvest of 136 sacs, but it did not generate net profit, with a negative balance of - $\mathrm{R} \$ 1.676,31$ remaining, with everything starting in the third year, the result of production begins to produce net profit, but that still doesn't match the expenses for next year's expenses.

The crop has an average useful life of 15 years (Embrapa, 2015), and the value of profits and expenses varies in the first years of production. According to the farmer, the crop has an average fixed value during 7 periods of production after the second harvest. In addition, after 7 years of harvesting it is necessary to perform partial harvesting, which consists of removing the oldest branches, which allows the younger branches to continue producing.

After the eighth harvest, that is, after the ninth year, production begins to decrease by about $10 \%$ per year until the end of the useful life, which is 15 years, where production is no longer viable. That way, by calculating the estimates of the next harvest, it was used as a basis for calculating the decrease of these $10 \%$ of production, thus, based on this percentage, the costs with the harvest were proportionally developed, that is, production decreases, reduces harvest costs (harvested amount paid per unit of measure, drying and FUNRURAL).

For the calculation of the viability indicators, the initial investment in the amount of $\mathrm{R} \$ 15.720,00$ was used, and the expenses and profits obtained in the crop during the estimated useful life, which on average is 15 years. Therefore, an expectation rate of $10 \%$ per year was used to calculate the Net Present Value (VPL), and to calculate the Internal Rate of Return (TIR).

Table 10 will present the financial viability indicators of the project considering Scenario 01, without the presence of scale insects in the coming years.

Table 10. Financial viability indicators for the project (Scenario 01)

\begin{tabular}{|l|l|}
\hline \multicolumn{2}{|c|}{ Project financial viability indicators } \\
\hline Indicators & Result \\
\hline Net Present Value (VPL) & $\mathrm{R} \$ 52.377,02$ \\
\hline Internal Rate of Return (TIR) & $27,85 \%$ per year \\
\hline Payback (PP) & 4,11 years \\
\hline
\end{tabular}

Source: Prepared by the authors 
At first, based on the data obtained with the indicators, the project is viable, due to the fact that the Net Present Value has a positive result and produces return for the investor. Therefore, the Internal Rate of Return showed a higher than expected indicator and was positive, thus generating an increase in investor wealth.

Due to the fact that coffee is a perennial crop, that is, it produces once a year, it means that the payback will occur from the fifth year, indicating that the farmer will have to wait between four and five years to make a profit, and keep with resources from another medium. If he has no way of earning income during all these years, he will turn to financial institutions. Not currently the case for the farmer, as he has another older plot of land in production, which has not been analyzed.

Table 11 shows the financial viability indicators for the project considering Scenario 02, with the presence of scale insects in the coming years.

Table 11. Financial viability indicators for the project (Scenario 02)

\begin{tabular}{|l|c|}
\hline \multicolumn{2}{|c|}{ Project financial viability indicators } \\
\hline \multicolumn{1}{|c|}{ Indicators } & Result \\
\hline Net Present Value (VPL) & $\mathrm{R} \$ 31.751,94$ \\
\hline Internal Rate of Return (TIR) & $20,28 \%$ per year \\
\hline Payback (PP) & 4,74 years \\
\hline
\end{tabular}

Source: Prepared by the authors

Table 09 shows how the financial viability values are affected if the scale insect is present every year of production, generating a decrease of R\$20,625.08 at the VPL, but which is still viable, since the result of the indicator was also resulting in profits for the investor.

The Payback in Scenario 02 increases in some months in relation to Scenario 01 meaning that the farmer will have an increase in waiting for the investment to be received. The Internal Rate of Return, in turn, showed a lower indicator than that presented in Scenario 01, but which also has a positive result.

From the results obtained with the project's feasibility indicators, it is observed that they present positive values, that is, a desired internal rate of return, a payback between four and five years and a positive net present value, resulting in a viable project to generate wealth.

\section{Conclusion}

The producers of Rondônia started to invest in the new culture of clonal conilon coffee, acquiring the new planting techniques, replacing their old crops with new crops of genetically modified coffee, however, they do not carry out an analysis of future investment planning, it without knowing how long the venture will receive an acceptable payback, and you can wait for that entire period.

The financial viability indicators indicate that the transition costs from an old common coffee crop to a new one present positive data, although, in the first two years of transition between one crop and another, the profit is equal to zero. The fourth harvest, on the other hand, presents a good return on investment covering all expenses with the enterprise.

Only the purely economic factors used were considered, based on the calculation of the indications of net present value, internal rate of return and payback, since the proposed objectives were to analyze the financial viability of a rural property inserted in the coffee context of the State of Rondônia .

It is understood that the result obtained presented a viable investment to the producer after the cash flow calculations. However, if the farmer does not have equity to support himself during the period between four and five years of non-profit spending on production, it will result in loans from financial institutions. Even so, the investment becomes viable, as from the fifth year it starts to earn profits. Thus, when carrying out the analysis of investment feasibility indicators, it is clear that the application of the resource has become viable for the producer due to its positive results.

Finally, investment in coffee cultivation in Rondônia becomes viable, considering that the results for the rural producer are positive over the years, including the support of the State that develops projects in order to increase production. Corroborating the result, the projections indicate an increase in world consumption, investment in coffee becomes viable, especially clonal conilon coffee, due to its higher productivity.

\section{References}

BONA, André. Conheça os métodos de análise de investimentos. Disponível em: https://andrebona.com.br/analise-de-investimentos/. Access in: 14 de out 2019. 2016.

CARVALHO, Carlos Henrique Siqueira de. Cultivares de café. Disponível em: http://www.sapc.embrapa.br/arquivos/consorcio/publicacoes_tecnicas/Livro_Cultivares.pdf. Access in: 25 nov 2019. 2008. 
CENTRO DE ESTUDOS AVANÇADOS EM ECONOMIA APLICADA - CEPEA/ESALQ. Indicador do Café Robusta Cepea/Esalq. Disponível em: https://www.cepea.esalq.usp.br/br/indicador/cafe.aspx. Access in: 22/11/2019. 2019.

CENTRO DE ESTUDOS RIOTERRA. Boletim Informativo do Projeto Quintais Amazônicos. Ano 02, edição $08,2016$. Disponível em: http://rioterra.org.br/pt/tag/amazonia/. Acesso em: 19 set. 2019.

COMITÊ DE PRONUNCIAMENTOS CONTÁBEIS. Sumário do pronunciamento técnico CPC 46. Disponível em: http://static.cpc.aatb.com.br/Documentos/395_CPC_46_rev\%2012.pdf. Access in: 14 de out 2019. 2012.

COMPANHIA NACIONAL DE ABASTECIMENTO - CONAB. Indicadores da Agropecuária. Observatório Agrícola. Ano XXVI, n 10 Outubro 2017.

COMPANHIA NACIONAL DE ABASTECIMENTO - CONAB. Indicadores da Agropecuária. Observatório Agrícola. Ano XXVIII, $\mathrm{n}^{\circ} 10$ Outubro 2019.

DIÁRIO DA AMAZÔNIA. Café ocupa área de 80 mil hectares. Disponível em: https://www.diariodaamazonia.com.br/cafe-ocupa-area-de-80-mil-hectares/. Access in: 25 de ago 2019. 2018.

EMPRESA BRASILEIRA DE PESQUISA AGROPECUÁRIA - EMBRAPA. Área utilizada com cultivo do café robusta no Brasil ocupa apenas 375 mil hectares em 2018. Disponível em:

https://www.embrapa.br/busca-de-noticias/-/noticia/37299776/area-utilizada-com-cultivo-do-cafe-robusta-no-brasi 1-ocupa-apenas-375-mil-hectares-em-2018. Access in 31 ago 2019. 2018 a.

EMPRESA BRASILEIRA DE PESQUISA AGROPECUÁRIA - EMBRAPA. Café Conilon: Alternativa para a Agricultura de Base Familiar na Região de Coruripe, AL. Disponível em: https://ainfo.cnptia.embrapa.br/digital/bitstream/item/142131/1/bp-100.pdf. Access in: 31 ago 2019. 2015.

EMPRESA BRASILEIRA DE PESQUISA AGROPECUÁRIA - EMBRAPA. Cafeicultura de Rondônia na vanguarda da tecnologia. Disponível em:

https://www.embrapa.br/busca-de-noticias/-/noticia/18383426/cafeicultura-de-rondonia-na-vanguarda-da-tecnologi a. Access in: 31 ago 2019. 2016.

EMPRESA BRASILEIRA DE PESQUISA AGROPECUÁRIA - EMBRAPA. Consumo mundial de café atinge 165 milhões de sacas no ano cafeeiro 2018-2019. Disponível em:

https://www.embrapa.br/busca-de-noticias/-/noticia/40814481/consumo-mundial-de-cafe-atinge-165-milhoes-de-sa cas-no-ano-cafeeiro-2018-2019. Access in: 25 ago 2019. 2019.

EMPRESA BRASILEIRA DE PESQUISA AGROPECUÁRIA - EMBRAPA. Evolução da cafeicultura brasileira nas últimas duas décadas. Disponível em:

http://www.sapc.embrapa.br/arquivos/consorcio/publicacoes_tecnicas/Consorcio-Embrapa-Cafe-Evolucao-21-1-19 .pdf. Access in: 25 ago 2019. 2017.

EMPRESA BRASILEIRA DE PESQUISA AGROPECUÁRIA - EMBRAPA. Produção dos Cafés do Brasil equivale a 36\% da produção mundial em 2018. Disponível em:

https://www.embrapa.br/busca-de-noticias/-/noticia/34724227/producao-dos-cafes-do-brasil-equivale-a-36-da-prod ucao-mundial-em-2018. Access in: 31 ago 2019. 2018 b.

ENTIDADE AUTÁRQUICA DE ASSISTÊNCIA TÉCNICA E EXTENSÃO RURAL DO ESTADO DE RONDÔNIA EMATER-RO. Relatório de atividades 2015. Porto Velho-RO, 2016.

ENTIDADE AUTÁRQUICA DE ASSISTÊNCIA TÉCNICA E EXTENSÃO RURAL DO ESTADO DE RONDÔNIA EMATER-RO. Relatório de Gestão e de Atividades 2016. Disponível em:

http://www.emater.ro.gov.br/ematerro/relatorio-de-atividades/. Access in: 05 de out. 2019. 2017.

ENTIDADE AUTÁRQUICA DE ASSISTÊNCIA TÉCNICA E EXTENSÃO RURAL DO ESTADO DE RONDÔNIA EMATER-RO. Relatório de Gestão e de Atividades 2017. Disponível em:

http://www.emater.ro.gov.br/ematerro/relatorio-de-atividades/. Access in: 05 de out. 2019. 2017.

ENTIDADE AUTÁRQUICA DE ASSISTÊNCIA TÉCNICA E EXTENSÃO RURAL DO ESTADO DE RONDÔNIA EMATER-RO. Relatório de Gestão e de Atividades $2018 . \quad$ Disponível em: http://www.emater.ro.gov.br/ematerro/relatorio-de-atividades/. Access in: 05 de out. 2019. 2018.

ENTIDADE AUTÁRQUICA DE ASSISTÊNCIA TÉCNICA E EXTENSÃO RURAL DO ESTADO DE RONDÔNIA EMATER-RO. Cafeicultura. Disponível em: http://www.emater.ro.gov.br/ematerro/cafeicultura/ Access in: 25 ago 2019. 2019.

ESPINDULA, Marcelo Curitiba; PARTELLI, Fábio Luiz. Vantagens do uso de clones no cultivo de cafeeiros canéfora 
(Conilon e Robusta). Embrapa Rondônia, Porto Velho - RO, 2011.

FANTINI, Caiki Calepso. Funrural - Quais são as alíquotas e como funciona o Fundo Rural?. Disponível em: https://blog.cefis.com.br/funrural/. Access in: 17 nov 2019. 2019.

FERRÃO, Romário Gava. et. al. Café Conilon. $2^{\circ}$ ed. Vitória, ES. 2017.

GIL, Antonio Carlos. Como Elaborar Projetos de Pesquisa. $4^{\circ}$ ed. São Paulo: Atlas, 2002.

INSTITUTO BRASILEIRO DE GEOGRAFIA E ESTATÍSTICA (IBGE). Nova Brasilândia D'Oeste. Disponível em: https://www.ibge.gov.br/cidades-e-estados/ro/nova-brasilandia-doeste.html. Access in: 29 nov 2019. 2019.

INSTITUTO FEDERAL DE RONDÔNIA - IFRO. Campus Cacoal e ABDI firmam convênio para implantação de laboratório de solos e plantas. Disponível em: https://portal.ifro.edu.br/cacoal/noticias/7573. Access in: 31 ago 2019. 2019.

LANNA, G. B. M. e REIS, R. P. Influência da Mecanização da Colheita na Viabilidade Econômico-financeira da Cafeicultura no Sul de Minas Gerais. Coffee Science, Lavras, v. 7, n. 2, p. 110-121, maio/ago. 2012.

MARCOLAN, Alaerto Luiz et. al. Cultivo dos Cafeeiros Conilon e Robusta para Rondônia. 2009.

MARCOLAN, Alaerto Luiz, et. al. Café na Amazônia. Brasília. Embrapa, 2015.

MOTTA, Regis da Rocha; CALÔBA, Guilherme Marques. Análise de Investimentos: tomada de decisão em projetos industriais. 1. ed. - 4. reimpr. São Paulo: Atlas, 2006.

PILÃO, Nivaldo Elias; HUMMEL, Paulo Roberto Vampré. Matemática Financeira e Engenharia Econômica: A teoria e a prática da análise de projetos de investimentos. São Paulo: Cengage Learning, 2012.

PORTAL DO GOVERNO DO ESTADO DE RONDÔNIA. Produção de café é incentivada com distribuição de mudas de alta qualidade. Disponível em:

http://www.rondonia.ro.gov.br/producao-de-cafe-e-incentivada-com-distribuicao-de-mudas-de-alta-qualidade/.

Access in 25 de ago 2019. 2017, b.

PORTAL DO GOVERNO DO ESTADO DE RONDÔNIA. Produtores de 36 municípios de Rondônia recebem mais de três milhões de mudas de café clonal. Disponível em:

http://www.rondonia.ro.gov.br/produtores-de-36-municipios-de-rondonia-recebem-mais-de-tres-milhoes-de-mudas -de-cafe-clonal/. Access in: 29 nov 2019. 2017, a.

PRAZERES, Rodrigo Máximo Lopes dos. Análise da Viabilidade Econômico-Financeira de um Empreendimento de Produção e Venda de Café no Norte do Espírito Santo. Monografia (Universidade Federal do Ceará). Fortaleza, 2016. Disponível em: http://www.repositorio.ufc.br/bitstream/riufc/35829/1/2016_tcc_rmlprazeres.pdf. Access in: 14 de out 2019.

RAMALHO, André Rostand et al. Progresso genético da produtividade de café beneficiado com a seleção de clones de cafeeiro 'Conilon'. Revista Ciência Agronômica, v. 47, n. 3, p. 516-523, 2016.SERVIÇO BRASILEIRO DE APOIO ÀS MICRO E PEQUENAS EMPRESAS - SEBRAE. Viabilidade Financeira. Disponível em: https://www.sebrae.com.br/sites/PortalSebrae/ufs/pr/artigos/viabilidade-financeira,4e8ccd18a819d610VgnVCM10 00004c00210aRCRD. Access in: 25 nov 2019.

SOUZA, Cleiton Santana de. Perspectivas de fortalecimento da agricultura familiar a partir do sistema de cultivo do café clonal: o caso do assentamento Margarida Alves em Nova União-RO. 2018.

WESTON, J. Fred; BRIGHAM, Eugene F. Fundamentos da Administração Financeira. 10. ed. São Paulo. Pearson Makron Boocks, 2004.

\section{Copyrights}

Copyright for this article is retained by the author(s), with first publication rights granted to the journal.

This is an open-access article distributed under the terms and conditions of the Creative Commons Attribution license which permits unrestricted use, distribution, and reproduction in any medium, provided the original work is properly cited. 